A vailable online at http://jddtonline.info

MINI REVIEW

\title{
GLIMPSE OF PHARMACY PROFESSION IN INDIA
}

\author{
Anant P. Hardas
}

Director at Indian Pharma Guidance Academy, Nagpur, (M.S.) INDIA-440010

Received 17 Feb 2012; Revised 15 March 2012; Accepted 15 March 2012, Available online 15 March 2012

\begin{abstract}
ABS TRACT
India has been one of the countries in the world whose past has been glorious. It is a country where others have gained knowledge, ethics and moral for their future prosperity. The Indian traditional systems of medicine have been Ayurveda, Siddha and Unani. Ay urveda and Siddha originated in India itself. In ancient India the sources of drugs were of vegetable, animal and mineral origin. They were prepared empirically by few experienced persons. Knowledge of that medical system was usually kept secret within a family. There were no scientific methods of standardization of drugs. In the field of medical or pharmacy profession, our country has a rich tradition and the following important milestones depict the history and development of pharmacy profession and education activity in India. In This short review author provides some of the glimpses of the pharmacy profession in India.
\end{abstract}

\section{INTRODUCTION}

Pharmacy is the health profession that links the health sciences with the chemical sciences and it is charged with ensuring the safe and effective use of pharmaceutical drugs. Nowadays in India Pharmacy profession is becoming very popular among individuals because of its vast scope World wide. In countries like India, people are now focusing to this profession apart from Doctors and Engineers. Parents are also interested to send their Son and Daughters to this profession. As a result numerous colleges and branches have been opened in this profession.

\section{MYTHOLOGY}

Lord brahma was the first teacher of universe who wrote "Ayurveda" (Science of life) in 5000 BC.

\section{VEDIC PERIOD}

Lord dhanwantris eas worshipped as "God of Health" holding the amrut (nector) in his hand. Righveda described the various herbs used in treating numerous diseases.

Charaka and sushrata spread the massage of Ayurveda in ancient India.

\section{PRE-HIS TORIC PERIOD}

BC 226-Hospital concept in the period of Great Ashoka was well developed and practiced in India.

AD Period

(C) 2011, JDDT. All Rights Reserved
900 AD- Tamilnadu (Tirumakku dal village) discovered organized hospital activity in India treating diseases like piles, jaundice, dropsy, TB, hemorrhage, etc.

1000 AD- All the medical works were madelled on the Charaka pattern of treatment of diseases

Europe was influenced by Indian drugs and herbs in 1500 century.

Portuguese physician cum teacher Garcia d aorta published a treatise: "Cologuious dos stroples a drogus da indica" describing various Indian herbs in 1563.

First general hospital was set up in Chennai in 1664.

Chennai medical college started at Chennai in 1835 and Calcutta Medical College, Calcutta in 1936.

\section{PRE-INDEPENDENCE ERA}

The western or the so-called Allopathic system came into India with the British traders who later become the rulers. Under British rule this system got state patronage. At that time it was meant for the ruling race only. Later it descended to the people and become popular by the close of 19th Century.

The history of pharmacy profession or practice in India starts with opening of chemist shop in 1811 by Scotch M Bathgate opened in Kolkata. This was probably the beginning of pharmacy practice in India. 
Hindustani version of London Pharmacopoeia available in India in the year 1824 is described to control pharmaceutical activities in India. This forced the Indian community to import drugs from overseas and pushed Indian pharmacy to rudimentary stage.

Goa medical college, started at Panjim, Goa in 1840. Bengal dispensary and pharmacopoeia-Vol 1 published from Calcutta, Editor Prof, WBO Shaugh Neesy, 1841. The devnagri transcription in hindi and Bengali of London pharmacopoeia made available in India in 1843. Bengal Pharmacopoeia and General conspecta of medicinal plants (Popularly known as Bengal Pharmacopoeia) published in 1864.

E.J Wang tabled the motion for publication of Indian Pharmacopoeia- $4^{\text {th }}$ march 1864. H.W. Honey, the "first qualified person" to get recognition as chemist and druggist in India in 1866. "First Pharmacopoeia of India" under British Monarchy in India was published in 1868.

Moder Sheriff, "Pharmacist" in Chennai College and Hospital, compiled "Venacular names of Indian Medicinal Plants and Herbs" in 1869 which formed the nucleus for "Indian Pharmacopoeia".

Starting of regular two years course for "Chemists and Druggists Diploma" at MMC, Chennai in 1874. Opium act implanted in 1878.

Pharmacy education pattern was based on the instructions provided by the pharmaceutical society of Great Britain. A formal training of the compounders was started in 1881 in Bengal.

"Chemists and Druggits Diploma" course of MMC, Chennai made equivalent to that os diploma issued by Royal Pharmaceutical Sociery of Great Britain, London, in 1893 (2 Years study +3 months practical training +1 year internship).

Jauary 1894- The Indian Journal of Pharmacy strated publishing from Calcutta but soon became defunct. 1898 Sea Customs Act Goods with 'false trade description' were prevented from importing under this act.

1901: Establishment of the Bengal Chemical and Pharmaceutical Works, Calcutta by Acharya P.C. Ray. 1903: A small factory at Parel (Bombay) by Prof. T.K. Gujjar.

1907: Alembic Chemical Works at Baroda by Prof. T.K. Gujjar.

\section{Bengal Excise Act}

1912 United Provinces (now Uttar Pradesh) Prevention of Adulteration Act Refers to adulteration of foods and drugs.

$1914 \mathrm{Pujab}$ Excise Act

Poison Act was passed in 1919.

1919 Bengal Food Adulteration Act.
In 1919 Bihar and Orissa Prevention of Adulteration Act was come.

1919 Madras Prevention of Adulteration Act Chiefly concerned with food adulteration.

November 1920- The first organized move to form a pharmaceutical society, the Calcutta Chemists \& Druggists Association released thid, which changed its name to Bengal Chemists \& Druggists Association in 1926.

The pioneer organization in the true sense of "Qualified pharmacists" was formed by the Chmeits \& Druggists of Chennai region in 1923 under thebanner of the Pharmaceutical Association which changed its name to Pharmaceutical Society of India in 1925 and practicised the profession of pharmacy upto 1950.

Government of India on 11th August 1930, appointed a committee under the chairmanship of Late Col. R.N.Chopra to see into the problems of Pharmacy in India and recommend the measures to be taken. This committee published its report in 1931. It was reported that there was no recognized specialized profession of Pharmacy. A set of people known as compounders were filling the gap.

In 1930, Dangerous drug act and Drug enquiry committee under the Chairmanship of Col. R.N. Chopra (Chopra Committee) was came.

Inclusion of pharmaceutical chemistry as a subject course at degree at Banaras Hindu University (BHU), Varanasi- great vision od Late Pt. Madan Mohan Malviya, 1932 - the then Vice Chancellor of BHU.

The first pharmaceutical society with education platform and view emerged in November 1935 under the banner of BHU Pharmaceutical Society which acted as a nucleus for the emergence of an All India Association - United Provinces Pharmaceutical Association (UPPA) registered in December 1935 but the name UPPA was soon replaced with Indian Pharmaceutical Association (IPA) in 1936 and first All India Pharmaceutical Conference was held at Banaras in January 1941.

Regular degree course (B.Pharm) started at BHU under the leadership of Prof. M.L. Shroff- "The Father of Indian Pharmacy" education in India- 1937-38 session. The course provided for studies in pharmaceutical chemistry, pharmacy, pharmacognosy, pharmaceutical economics and German Human physiology and pharmacology were not included. The graduates generally preferred to go for jobs in pharmaceutical manufacturing and analysis. It was later that human physiology and pharmacology got to form part of the syllabus at the BHU.

First issue of Indian journal of Pharmacy was released in 1939- Official publication of IPA.

In 1940 Prof. Schroff introduced M.Pharm at BHU, Varanasi. 
Subhadra Kumar Patni became the first Pharmacy Graduate in India in 1940 - Formation of Pharmacy and Allied Manufacturers \& Distributirs Association Ltd. (PAMDAL) head quartered at Mumbai.

1940: Govt. brought 'Drugs Bill'to regulates the imort, manufacture, sale and distribution of drugs in British India. This Bill was finally adopted as 'Drugs Act of 1940'. The Drug Act partly implanting Chopra Committee 1941 - First ever holding of All India Conferences of IPA at BHU, Banaras.

Post of Hospital Pharmacist created at KEM Hospital, Mumbai, 1941 (Modern pharmacy services started at CMCH, Vellore; Jaslok; JJ Hospital and other hospitals in India).

Go rakh Prasad Srivastava became the first Post Graduate in Pharmacy from BHU in 1943.

The University of the Panjab, Lahore, which came next to institute the degree course in pharmacy in 1944, aimed at producing man power particularly for professional pharmacy. Dr Khem Singh Grewal was the founder of pharmaceutical education at the Panjab University, the nucleus he created now stands as the famous University Institute of Pharmaceutical Sciences of the Panjab University at Chandigarh. Grewal became an accomplished pharmacologist. As Professor of Pharmacology he headed the Department of Pharmacology at the K. E. Medical College (1940-47).

PhD degree in Pharmaceutical Sciences is started in 1945 at BHU.

Drug and Cosmetic Act and Rules have effective in 1945.

Association of Pharmaceutical Teachers of India (APTI) was formed in 1946.

1945: Govt. brought the Pharmacy Bill to standardize the Pharmacy Education in India 1946: The Indian Pharmacopoeial List was published under the chairmanship of late Col. R.N. Chopra. It contains lists of drugs in use in India at that time which was not included in British Pharmacopoeia.

Health survey Development Committee (Bhore Committee) report tabled in 1946 recommending 3-tier system of pharmacy education in India, viz, diploma-degree and technologists in pharmacy

\section{POST INDEPENDENCE ERA}

Indian Pharmaceutical Congress Association (IPCA) was floated in 1948 at Calcutta and the first annual conference was held in Calcutta itself in December 1948 with Prof. M.L. Shroff as a president Elec. But this address was read in absentia which a surprise was for everybody.

1948: Indian Pharmacopoeial Committee was constituted under the chairmanship of late Dr. B.N. Ghosh. The statutory regulation of pharmacy institutions in India was established with the enactment of the Pharmacy Act 1948, and The Pharmacy Council of India was established in the year 1949 and the first education regulations (ER) framed in 1953, which were subsequently amended in 1972, 1981 and 1991.

The Pharmacy Act passed in 1948- Constitution of Pharmacy Council of India (PCI) and framing of Education Regulations (ER) under section 19 of the Act.

First Diploma in Pharmacy education institute started at Jalpaiguri, 1949 at West Bengal.

Education Regulation of PCI laid down Diploma of Pharmacy (D.Pharm) as the minimum qualification to enter into the profession of pharmacy in India-1953.

Sheovihari Lal became the first PhD holder in Pharmacy field, obtaining his Doctorate degree from University of Patna (Patna Medical College) under the guidance of Dr Achari, Department of Pharmacology, 1953.

Unification of IPCA \& IPA took place in March 1954 and it was resolved that IPCA will hold annual conferences and all other professional activities will be carried out by IPA and subsequently the first joint conference of the congress was held at Baroda.

Pharmacy Enquiry Committee Report 1954 (Major General S.L. Bhatia) recommended pay scales for pharmacists. Drugs and Magic Remedies (Objectionable Advertisements) Act 1954 was passed to stop misleading advertisements (e.g. Cure all pills) in 1954.

1955: Medicinal and Toilet Preparations (Excise Duties) Act 1955 was introduced to enforce uniform duty for all states for alcohol products.

1955: First Edition of Indian Pharmacopoeia was published.

Master of Pharmacy syllabus was drafted by AICTE in 1960.

Indian Drug Manufacturers Association (IDMA) was founded in 1961 .

Formation of Indian hospital Pharmacists Association (IHPA) in 1963, head quartered at New Delhi.

First issue of Indian journal of Hospital pharmacy was published in 1964.

Organization of Pharmaceutical Producers of India (OPPI) established in 1965 which has head quarter in Mu mbai.

Second Edition of Indian Pharmacopoeia released in 1966.

India joined the Commonwealth Pharmacutical Association (CPA) as constituent member in 1970.

Nayudamma Committee directed holding of GATE examination for M.Pharm courses with scholarship in 1978.

All India Organization of Chemists \& Druggists (AIOCD) formed, merging all the other bodies in 1979.

Establishment of Pharmacy graduates Association (IPGA) on 1980. 
Amendment in Pharmacy Act 1948 to restrict the practice of pharmacy to "Qualified Registered Pharmacists" only was done in 1984.

Third Edition of Indian Pharmacopoeia released in 1985.

In 1985, Narcotic and Psychotropic Substances Act has been enacted to protect society from the dangers of addictive drugs.

Establishment of National Institute of Pharmaceutical Education \& Research (NIPER) at Mohali 1991 and Dr C.L. Kaul appointed as the First Director.

All India Board of Pharmaceutical Education and National board of Accreditation was formed in 1994.

Drug price Control Order formed in 1995.

Fourth Edition of Indian Pharmacopoeia released in 1996.

The Pharmacy Council of India (PCI), The Indian Pharmaceutical Association (IPA) and leaders of pharmacy profession have undertaken several initiatives including the rolling out of the Charter of Pharma Vision 2020, released by His Excellency Dr. A.P.J. Abdul Kalam, during 55th IPC 2003 at Chennai and roadmap document during 58th IPC 2006 at Mumbai proposing various activities to shape the future of pharmacy profession and pharmaceutical services in India by 2020.

Fifth Edition of Indian Pharmacopoeia was published in 2007.

The Pharm.D regulations u/s 10 of the Pharmacy Act 1948, have been notified in the Gazette of India on10thMay, 2008 with an aim to equip the future pharmacist of India with skills of not only dispensing medicines but also to serve as counselor of medicines with focus towards patients and prescriber of drugs. The 6-year PharmD and 3-year postbaccalaureate PharmD began to be offered as professional degree programs in India focused mainly toward clinical and community aspects of the profession and mandatory practical training at practice sites. The Pharm.D program is comprised of 6 academic years, with 5 years of study and 1 year of internship and residency at a practice site. Six months of the internship and residency are spent in a general medicine department and 2 months each in 3 other specialty departments.

In this way, the professional and educational activities in the field of pharmacy in India are an ongoing process for ensuring the qualitative and quantitative changes in the total healthcare system of India.

\section{CURRENT STATUS OF PHARMACY PROFESSION IN INDIA :}

The Pharmacy education in our country has witnessed tremendous expansion in last one decade. However, the standards in education have been eroded by rising tides of mediocrity. There is an urgent need to initiate an academic exercise aimed at attaining revamping of curriculu m keeping in pace with current and emerging trends in the field of pharmacy. We have today 6 lacs pharmacists in the country, of which lacs are in community pharmacy. Diploma holders largely handle the pharmacy profession and the providing of quality pharmaceutical care is still a dream. However, significant developments underway may change the situation-

$>$ Increase in consumer awa reness

$>$ Awareness among the pharmacists on the need to provide direct patient care

$>$ Entry of international players in community pharmacy and health insurance

$>$ Increasing foreign direct investment in health industry

$>$ Increase in awareness that quality pharmaceutical care can be delivered only by pharmacists trained in direct patient care

The admissions to undergraduate courses (B. Pharm) have fallen down drastically during 2008-09 session, (nearly $40 \%$ seats are lying vacant across the country and the situation is worst for D. Pharm course where admissions are in single digits in many colleges). The slowing down of economy is expected to affect the job opportunities for the post-graduates (M. Pharm) in the coming years.

Author's Detail:

Prof. Anant Prabhakar Hardas, (M.Phar,.DBM, AIC $\{$ Ph.D $\})$

Director, Indian Pharma Guidance Academy

52, Madhav Nagar, NAGPUR- 440010 (M.S.) INDIA

Email:profaphardas@rediffmail.com, M - 09422806988 